\title{
Perceptions of ELT Students Related to Learner Autonomy in Language Learning
}

\author{
${\text { Gokhan } \text { Yigit }^{1} \& \text { Ozgur Yildirim }}^{1}$ \\ ${ }^{1}$ Anadolu University, Faculty of Education, Eskisehir, Turkey \\ Correspondence: Gokhan Yigit, Anadolu University, Faculty of Education, Eskisehir, Turkey
}

Received: May 3, 2018

Accepted: July 17, 2018

Online Published: August 3, 2018

doi:10.5430/ijhe.v7n4p76

URL: https://doi.org/10.5430/ijhe.v7n4p76

\begin{abstract}
This study mainly aims to investigate the perceptions of ELT (English Language Teaching) students related to learner autonomy in language learning. In order to have a deeper understanding of the perceptions of ELT students related to learner autonomy a total of 20 students are interviewed. The findings gathered are analyzed according to the year of study in the ELT program (from $1^{\text {st }}$ year to $4^{\text {th }}$ year) and gender of the participants. Content analysis is done for the qualitative data and the findings of the qualitative data are organized according to the students' study years and their gender. The findings indicate that the participants mainly state similar responsibilities, abilities, and activities in terms of their year of study. In addition, qualitative data reveal that although both female and male participants give importance to similar aspects related to responsibilities, abilities, and activities on learner autonomy, they state different reasons for giving importance to those aspects. Additionally, participants give some definitions related to learner autonomy and they prove how versatile the notion of learner autonomy is.
\end{abstract}

Keywords: learner autonomy, English language teaching, teacher education, year of study, gender

\section{Introduction}

\subsection{Background to the Study}

Language teaching in recent decades has faced many innovations in terms of both language teaching methodology and the roles of the stakeholders such as learners and teachers. There are innumerable changes in the methodology of teaching, and many approaches and methods have been introduced to enlighten language teaching pedagogy. The changes in these years have crucial effects on the methodology of language teaching. For example, Communicative Language Teaching (CLT), which aims to develop communicative competence of learners (Richards \& Rodgers, 2001, p. 159), prioritizes the communicative needs of language learners, and this leads to the development of learner-centered approach, which is an idea that learners are responsible for their own learning including all aspects of language learning (Richards \& Schmidt, 2010, pp. 326-327).

Since learner-centered approach is crucial in language learning, the endeavors to increase the learners' involvement in designing their language learning process should be prioritized. In the light of these advancements in language teaching, the learners are expected to gain control over the language learning processes, and this has revealed the notion of learner autonomy, which is defined as "the ability to take charge of one's own learning" (Holec, 1981, p. $3)$.

As a product of Western societies, learner autonomy has attracted the interests of the researchers from different cultures in recent years, and it has profoundly affected the other cultures that seem totally opposed to the concept of education in Europe. According to Palfreyman (2003, p. 1), many reasons can be put forward to favoring learner autonomy in language education: learner autonomy promotes human rights, and it is an effective approach to language learning. However, the researchers from other cultures have debated the effectiveness of learner autonomy since the educational settings differ from each other as well as the educational philosophies of these nations. For example, the cultural differences between the West and the East have been asserted to influence the perceptions of learners and teachers on learner autonomy. In other words, the term "autonomy", which is a notion of Englishspeakers' ideology (Holliday, 2003, p.111), can be understood differently by the learners because of their cultural backgrounds. Although learners' decision-making is supported in western cultures, Confucian values in the eastern cultures do not encourage students to question the learning (Liu \& Littlewood, 1997). Instead, learners are expected to show obedience to their teachers in eastern cultures. 
As mentioned in the relevant literature, culture is an indispensable notion for the realization of learner autonomy; thus, the current research focuses on ELT (English Language Teaching) students' perceptions related to learner autonomy in Turkey. By ELT students, we refer to EFL (English as a Foreign Language) teacher candidates enrolled in an English Language Teaching Department at a state university in Turkey. In other words, the main aim of the current study is to investigate the perceptions of ELT students in Turkey to shed light on how they perceive being autonomous in language learning.

Since the development of learner autonomy is one of the educational objectives (Chan, 2001) of the nations, it has been rather emphasized to increase the learners' responsibilities for their own learning in educational settings. Therefore, to become autonomous learners, the students are expected to develop their abilities to take responsibilities for their own learning. On the other hand, although several abilities to be developed for becoming an autonomous learner have been proposed, learners' experiences on language learning is considered one of the basic factors for the development of learner autonomy (Chan, Spratt \& Humphreys, 2002). However, relevant studies reveal that the learners do not always have sufficient experience in how to become an autonomous learner (Chan, 2001; Spratt, Humphreys \& Chan, 2002). It should be noted here that promoting learner autonomy is accepted to be highly crucial for increasing the learners' awareness on language learning process, but there are limited studies that investigate the promotion of learner autonomy (Kristmanson, Lafargue \& Culligan, 2013). On the other hand, Little (1991, p.7) states that learners should create their own purposes, determine the content, and the way the learning will occur by using their past learning experiences. Therefore, defining the perceptions of learners in terms of the experiences the students have in language learning is an important factor. For this reason, one of the aspects of the current study is to define the perceptions of ELT students from their first year to the fourth year with a broader sense in order to see whether learning experience has an effect on their view related to learner autonomy.

The main aim of this study is to investigate the perceptions of learners related to responsibilities, abilities, and activities on learner autonomy with regard to their learning experiences. In other words, this study aims to define the relationship between the learners' study years in ELT department and their perceptions related to learner autonomy in a broader perspective. The focus of this study is to explore the perceptions of learners on learner autonomy regarding the experience the students have, because several studies in the literature take the issue from only a narrow perspective, or the focus of these studies is not to explore whether any changes occur during the whole process of learning a language. For example, Ahmadzadeh and Zabardast (2014) investigate only the perceptions of the third year university students at two state universities in Turkey. Again, Y1ldirm (2005) focuses on the perceptions of the first and fourth year students in ELT department of a state university in Turkey. These studies show that there is a need to identify learners' perceptions by beginning from the first year to the last year in language learning in order to see whether learning experience has an effect on the perceptions of Turkish ELT students related to learner autonomy.

As stated earlier, autonomy is a complex notion; therefore, to explore the learners' perceptions related to learner autonomy is a challenging work for the researchers. One challenge of defining the perceptions of learners stems from the learner differences. For example, Brown (2007, pp. 234- 235) states that language learning is highly affected by the learners' gender. He informs that the differences between males and females can be one of the factors that affect language production. In other words, in his study he realizes that there are a number of differences between males and females in terms of their language use such as the usage of hedges, tag questions etc. This indicates that learners may have different choices in language learning in terms of their gender. On the other hand, the studies focusing on the perceptions of learners related to learner autonomy are limited in terms of gender. For example, Üstünoğlu (2009) investigates the perceptions of Turkish university students related to responsibilities, abilities, activities that students should have to become autonomous learners in terms of gender and motivation. The data are gathered from 320 university students and 24 teachers. The findings indicate that students perceive themselves autonomous but they do not take responsibilities for their learning. The results also indicate that there is not any difference in the perception scores of participants related to responsibilities in terms of gender although the perceptions of learners related to ability and activity scores differ statistically regarding the gender in that female students have more positive perceptions than male students do. Therefore, investigating the role of gender on learner autonomy may provide valuable information to the literature. There are several studies conducted to investigate the learners' perceptions related to learner autonomy from different perspectives in different contexts (Chan, 2001; Reinders, 2010; Kristmanson, Lafargue \& Culligan, 2013). However, gender and learner autonomy relation has not attracted the researchers' interests much, and thus, there are limited studies focusing on investigating the effects of gender on learner autonomy (Leathwood, 2006; Üstünoğlu, 2009). For this reason, the present study aims to explore the 
relationship between gender and perceptions of Turkish ELT students related to responsibilities, abilities, and activities on learner autonomy.

There are a number of definitions of autonomy made by the researchers in the literature; however, it has not been enlightened how learners define the concept of autonomy. Therefore, the present study also seeks to find out how learners define the concept of learner autonomy.

\subsection{Research Questions}

Considering the aims stated above, the following research questions have been tried to be answered in the current study:

1. Does the year of study have an effect on the perceptions of Turkish ELT students related to (a) responsibilities, (b) abilities, and (c) activities on learner autonomy?

2. Does gender have an effect on the perceptions of Turkish ELT students related to (a) responsibilities, (b) abilities, and (c) activities on learner autonomy?

3. How do Turkish ELT students define the concept of learner autonomy?

\section{Method}

\subsection{Participants}

Convenience sampling is applied in this study because, in convenience sampling, those who are conveniently available and eager to participate in the study are chosen as participants (Onwuegbuzie \& Collins, 2007). In this sense, Turkish ELT students enrolled in a state university in Turkey are chosen as the participants of the present study because of the practical reasons such as availability and reachability of the participants.

Throughout the program, Turkish ELT students take many courses focusing on different aspects of language learning. At their first year, they take courses related to language skills such as reading, listening, writing, speaking, and grammar as well as other courses like learner autonomy. From the second to fourth year of the program, the students take a number of methodology courses focusing on how learners can become good English teachers. In the last year, the program provides opportunities to learners in gaining experience on how to teach English in state schools with the courses like Teaching Practicum.

\subsection{Data Collection}

Semi-structured interviews with 20 participants, five participants from each study year have been conducted in the spring semester of 2016-2017 academic year. The participants have been asked about their perceptions of responsibilities, abilities, and activities related to learned autonomy in learning a language. The interview sessions have been tape recorded and then transcribed by the researcher. In addition, the characteristics of collecting qualitative data (Cresswell, 2013) are defined in a way that the atmosphere that interviews are conducted should be in a natural setting as much as possible, and the researcher should make the participants feel comfortable during the interview sessions. Therefore, the language used in the interviews is the native language of the participants, that is, Turkish, in order not to set a language barrier for the participants. Since the interviews are conducted in the native language of learners, the findings such as codes and themes and the quotations from the interview data have been translated into English before they are put in the results section.

\subsection{Data Analysis Procedure}

For ensuring reliable results, 20 percent of the qualitative data have been analyzed by a second rater. Inter-rater reliability between two raters has been found as .88 (Pearson's r). When there has been a mismatch between the raters in the coding procedure, the raters have negotiated on the mismatched codes and then they have reached a consensus.

Provisional coding has been used for the analysis of the qualitative data. This type of coding is constituted from a predetermined list of codes from the relevant literature, and new codes can also be added to the list or codes which exist in the list can be eliminated (Saldaña, 2009). Provisional coding is selected for analyzing the data in the present study because "this method is appropriate for qualitative studies that build on or corroborate previous research and investigations" (Miles, Huberman, \& Saldana, 2014, p. 60).

In the process of data analysis, firstly the data have been thoroughly read. For the second reading, memo notes have been jotted down, and then, codes have been created in consideration of memo notes and pre-existing codes. Later on, the codes have been placed under pre-determined categories and themes, which seek to find answers to the research questions in the present study. 


\section{Results}

\subsection{The Year of Study and Perceptions of Turkish ELT Students Related to Responsibilities on Learner Autonomy}

Regarding interview data, the perceptions of learners related to responsibilities on learner autonomy have been analyzed according to the participants' study years, from the first year to the fourth year, in ELT department at a state university in Turkey. Figure 3.1. presents the relationship between the perceptions of learners related to responsibility and the year of study on learner autonomy.

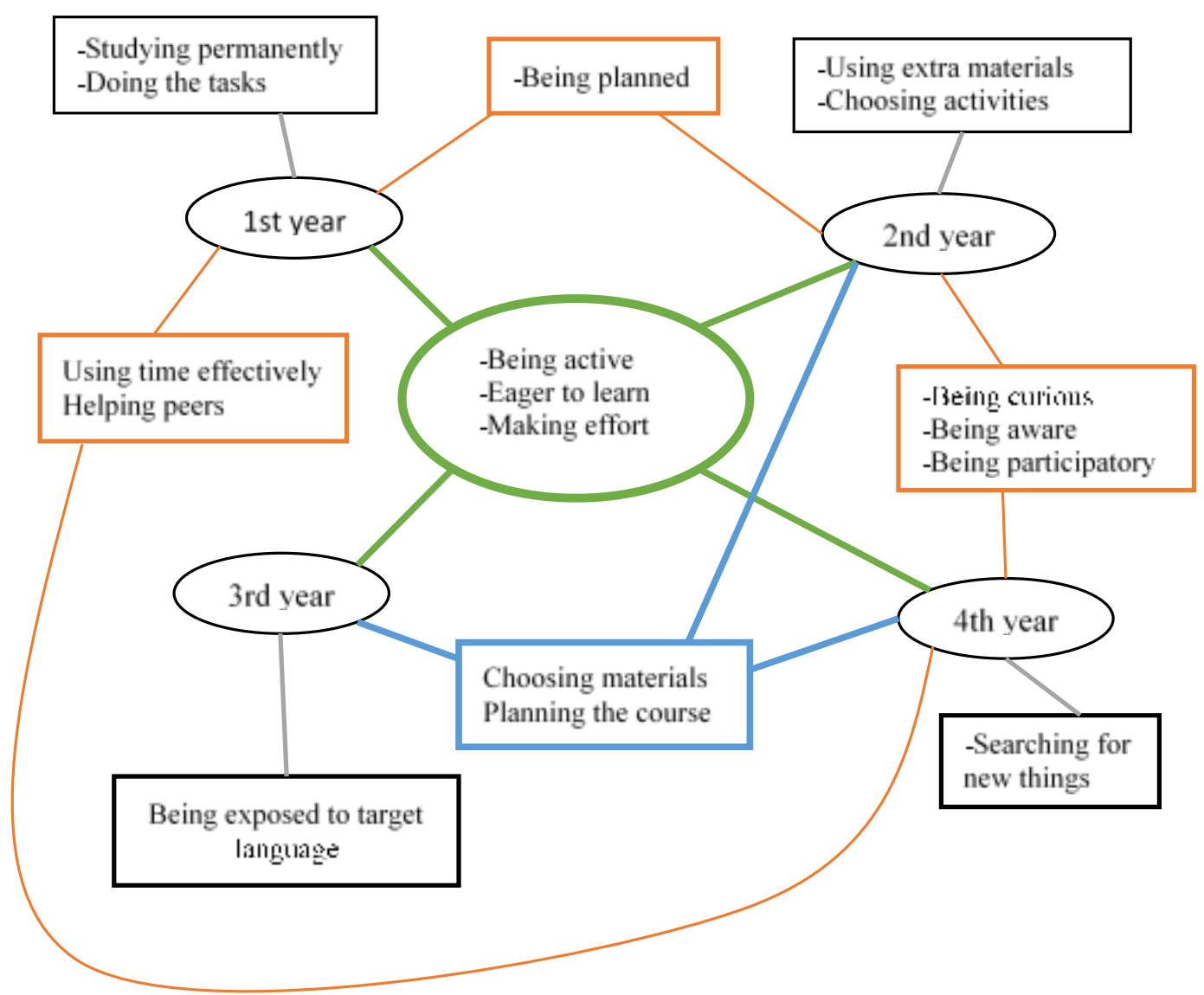

Figure 1. The relationship between the perceptions of learners related to responsibilities and the year of study

According to Figure 3.1., the results indicate that interviewees from the first year to the fourth year accept that learners should be responsible for "being active" in language learning. One of the interviewees (fourth year) says; "Learner should be the most active person in language learning process. The learning process is not transferring the knowledge, but, it is a process of searching new things. In conclusion, learners should be active and responsible for their learning". The other important responsibilities for all the interviewees are the learners' being "eager to learn" new things, and "making effort" in the language learning process. Learners should desire to learn new things in the target language because learning can be achieved only through the endeavors of learner since the roles of learners are indispensable in learning settings.

Different from the first year students, interviewees who are in the second, third, and fourth years in ELT department report that learners should have responsibilities in "choosing learning materials" and "planning the course". In traditional teacher- centered education, generally learners are not given any options to take part in any stages of learning a language. However, with the new approaches to language learning, it has been realized that the learners should be given certain roles in all stages of the learning process. 
Interestingly, the first and the fourth year interviewees state that learners should be responsible for "using time effectively" although the other interviewees who are at the second and the third year do not mention it. In addition, they also perceive that "helping their peers" is one of the responsibilities of learners in language learning. On the other hand, the first and the second year students explain that "being planned" is crucial when working on the subjects because doing a plan in language learning may guide learners to increase their knowledge in the target language. Learners can develop their autonomy through organizing the things that they should do.

For the interviewees who are at the second and fourth years, on the other hand, "being curious" about learning about what to learn, "being aware" of his/her learning process and "being participatory" are the other responsibilities in language learning. Involvement of learners in the classes is one of the goals of the new approaches to language learning. Learner autonomy, in itself, aims to integrate learners to decision making processes because autonomy is defined as a process that learners are aware of their learning process.

\subsection{The Year of Study and Turkish ELT Students' Perceptions Related to Abilities on Learner Autonomy}

Figure 3.2. presents whether the year of study has an effect on the learners' perceptions of abilities related to learner autonomy.

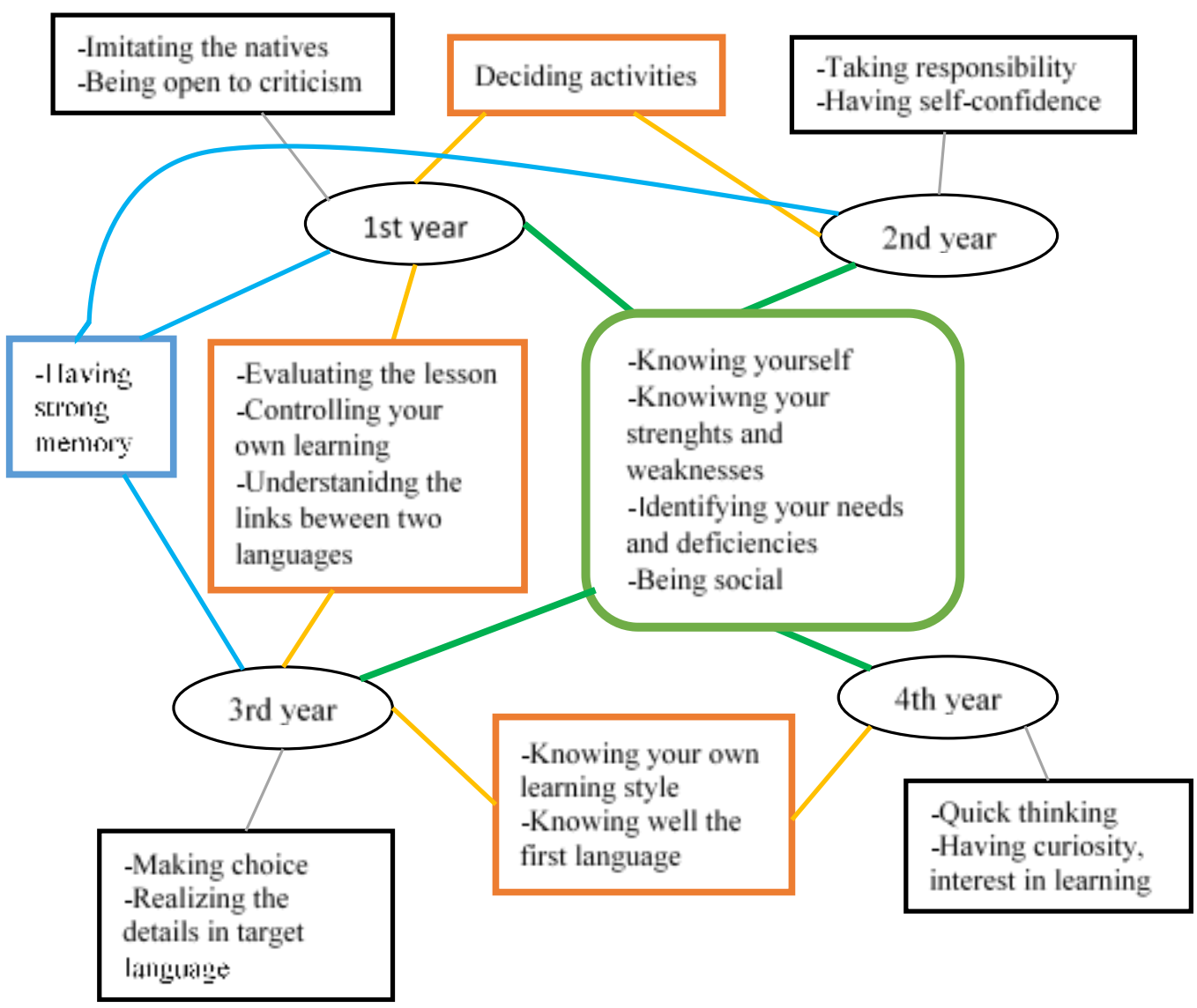

Figure 2. The relationship between the perceptions of learners related to abilities and the year of study

For the abilities that a learner should have in language learning, findings indicate that the interviewees, from the first year to the fourth year, explain that "knowing yourself" is an important issue in learning a language. Knowing yourself means knowing how to learn a language as a learner. For example, an interviewee (third year) states: "A learner may know how to learn better or decide in which way s/he can be successful in language learning". Therefore, knowing yourself as a learner may result in "knowing weaknesses and strengths of yourself" which is one other ability that interviewees among all groups define it as the ability learners should have in language learning. "Being 
social" is an ability that is uttered by the interviewees from all years. They state that being social is important because language is something that has communicative aspects and learners should be social to develop a communicative side of the language. The interviewees among all groups also state that learners should have the ability to "identify your needs and deficiencies" in learning a language because knowing what is lacking in your target knowledge and knowing what you need may help you decide what to learn first as a learner.

Apart from the fourth year interviewees, the others state that "having strong memory" is a crucial ability that learners should have in language learning because there are a lot of things to be memorized such as vocabulary, linguistic features of a language, and even some expressions peculiar to that language. Therefore, learners should have a strong memory since they need to remember the things in the target language.

According to interviewees who are the first and second-year students, "deciding activities" to be used in the language is also an important ability to be developed for the learners. On the other hand, having the ability to "evaluate the lesson" is important for the first and the third year interviewees. Besides this, "controlling your own learning" and "understanding the links between the two languages", that is, understanding the relationship between the first language and the target language are the other important abilities the learners should have while learning a language.

For the third and fourth year interviewees, "knowing your own learning style", that is, knowing whether you are learning a language better with visuals or you are a better learner by listening audios is one of the most important abilities that learners should have in language learning. In addition, "knowing well the first language" of yourself can be said an important ability to be developed for the third and fourth year interviewees because knowing the rules of their native language may help learners better understand the structure of the target language.

\subsection{Year of Study and Turkish ELT Students' Perceptions Related to Activities on Learner Autonomy}

Figure 3.3. shows the relationship between the perceptions of learners related to activities on learner autonomy and year of study.

For the perceptions of learners related to activities, we can say that learners' perceptions related to activity choices don't differ much according to the learners' study years in ELT department. All the interviewees from the first year to the fourth year state that they have the same perceptions related to applying activities concerning the basic language skills such as speaking, listening, reading, and writing. For example, an interviewee (fourth year) states the value of speaking activities with these words: "For me, the best evidence of knowing a language is to communicate with others in that language; therefore, learners should pay attention to speaking activities more when learning a language". Apart from the basic language skills, "watching films/TV series" is one of the most preferred activities for all the interviewees.

On the other hand, according to the interviewees who are at the first, second and fourth years, doing "vocabulary activities" is useful for the learners to improve their language proficiency. Besides this, for the interviewees who are at the first, third, and fourth years, "pronunciation activities" should be done to improve learners' speaking skills. Interviewees also state that "studying on grammar" and "doing grammar activities" are crucial although language education in Turkey put much emphasis on this issue because they state that they will be English teachers in near future, therefore they need to develop the linguistic competence of themselves more when compared to other learners of English. They also state that "role play activities" are valuable for language learners, because learners experience the language with role play activities. 


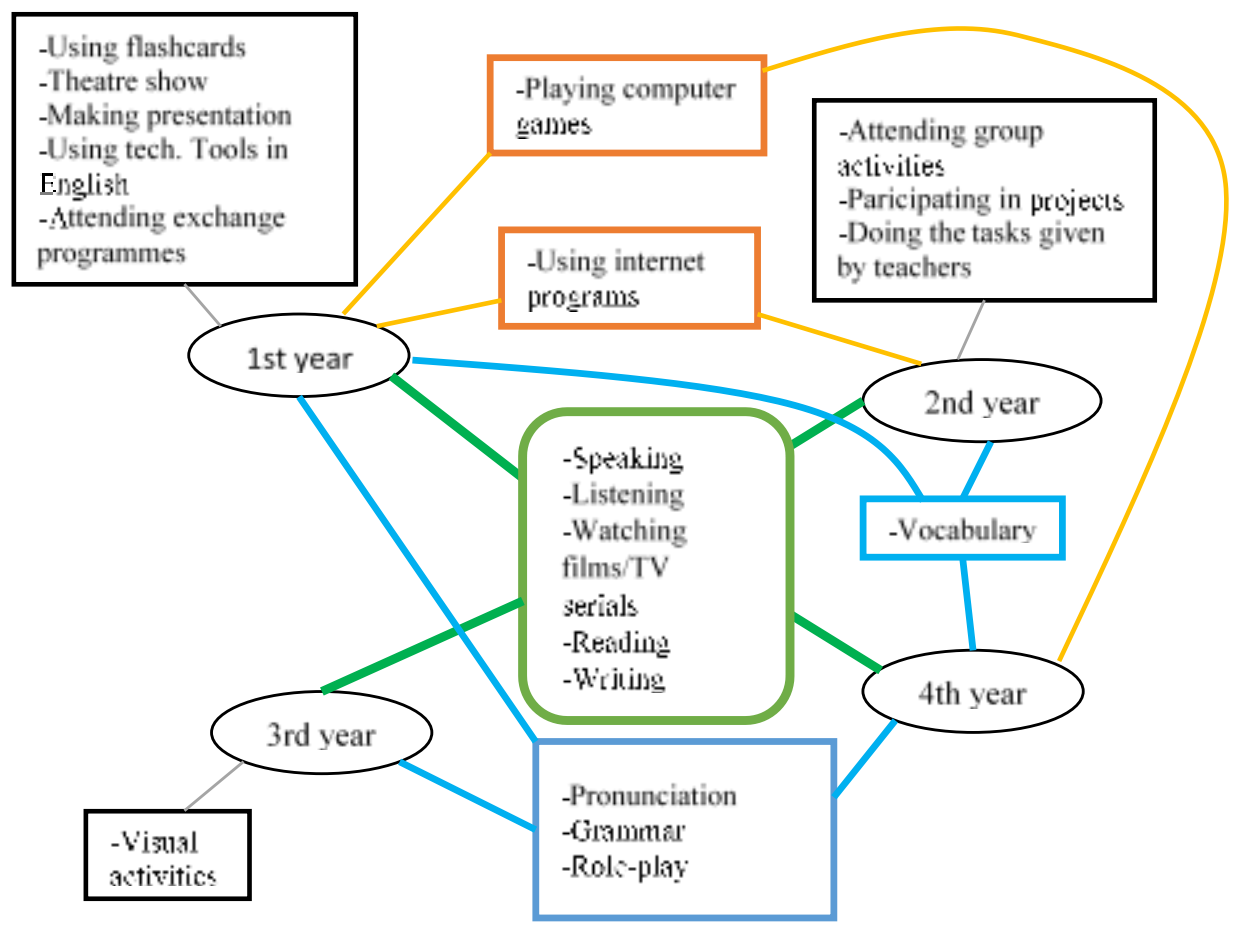

Figure 3. The relationship between the perceptions of learners related to activities and year of study

With the development of technologies and web tools, we see that many internet applications are used by learners. The first and second-year interviewees report that online sources can be used for learning a language as well as other sources. In addition, "playing computer games" for language learning is mentioned by the interviewees who are at the first and fourth years. In other words, they improve their knowledge in the target language with the things they get fun like computer games. 


\subsection{Gender and Turkish ELT Students' Perceptions Related to Responsibilities on Learner Autonomy}

Figure 3.4. shows the relationship between the perceptions of learners related to responsibilities and gender.

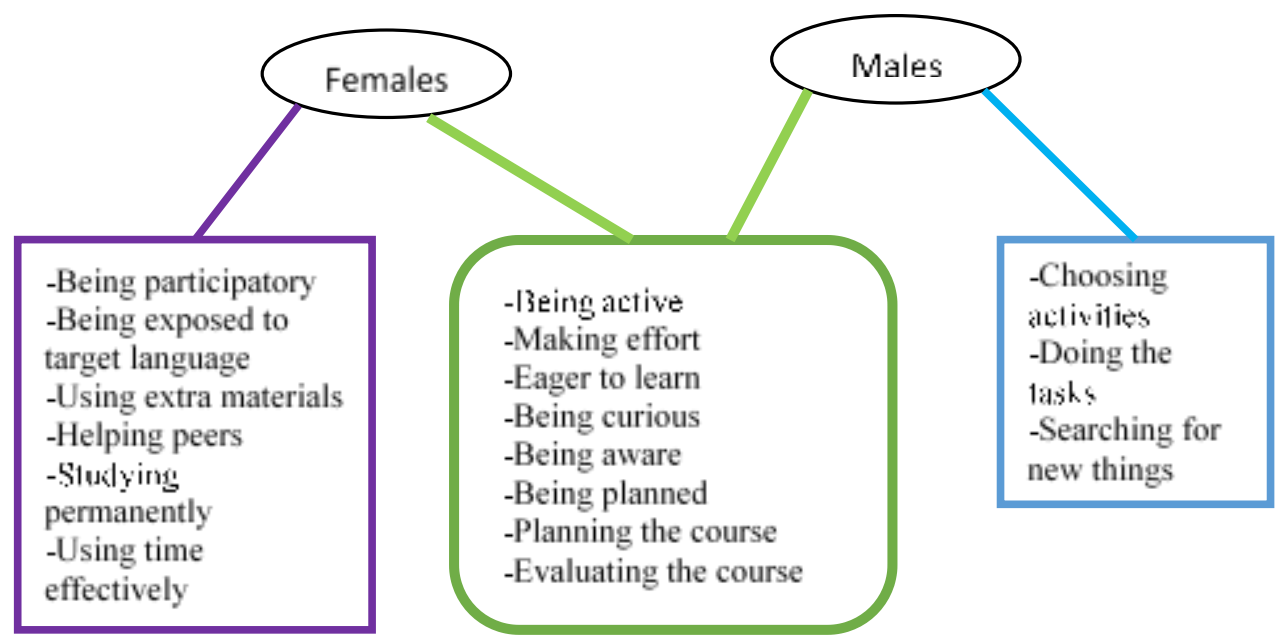

Figure 4. The relationship between the perceptions of learners related to responsibilities and gender

Learners' perceptions related to responsibilities on learner autonomy have been asked to the interviewees. Both female and male interviewees report that "being active" and "making effort" are the most important responsibilities that learners perceive in language learning because it is only the endeavors of learners that language learning can be achieved. In addition, both female and male interviewees state that learners" being "eager to learn" and "being curious" about learning a language is important. Besides, it is stated that "being aware" of the learning process is an important responsibility for the interviewees because learners should be aware of what they learn, and how they learn. Again, both female and male interviewees inform that "being planned" in language learning is one of the responsibilities that learners should have. Being planned is crucial because learners can be successful by planning what and when to learn.

In terms of gender, it could be said that there are a few differences between female and male explanations in the interview data. Female interviewees report that "being participatory" in classroom activities is one of the perceptions of learners related to responsibilities in language learning since they are actively involved in language learning process. In addition, they perceive that "being exposed to target language" is also an important responsibility for language learners. Female interviewees also state that learners should be responsible for "using extra materials" in learning a language, since the materials provided by the teachers may not be enough to increase knowledge of learners in the target language. A number of methods of language learning emphasize the significance of collaborative learning; therefore, learners should help each other. In this regard, female interviewees inform that learners should be responsible for "helping peers". Besides, female learners perceive that "studying permanently" is an important responsibility for the learners because learning a language may not be achieved in a short time. The female interviewees also inform that learners should "use time effectively" in language learning.

For the male interviewees, learners perceive that they should have the responsibility of "choosing activities" used in the classroom. As stated earlier, learners should have the opportunity to control over their learning; therefore, they should be responsible for every aspect of learning such as choosing activities. Male interviewees also inform that learners should be responsible for "doing the tasks" given by the teachers because teachers have experience in teaching a language; therefore, the tasks given by teachers are valuable for the learners to develop their target language. In addition, for the male interviewees, learners should be curious about "searching for new things" related 
to the target language. According to male interviewees, learning new things in the target language increases interests of learners to learn much more about target culture, and by this way, they can increase their knowledge in the target language.

\subsection{Gender and Turkish ELT Students' Perceptions Related to Abilities on Learner Autonomy}

Figure 3.5. shows the relationship between abilities and gender.

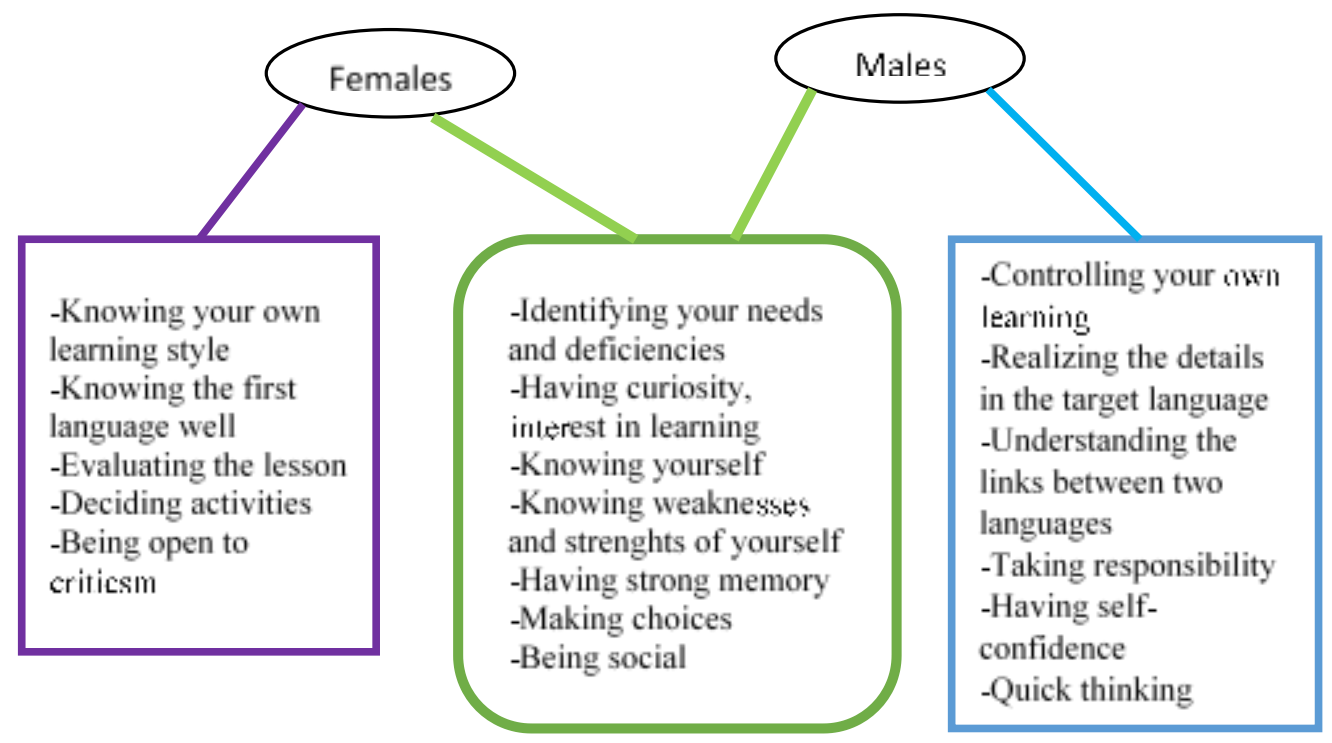

Figure 5. The relationship between abilities and gender

When we investigate the interview data, we realize that interviewees state a number of abilities learners should have in language learning. Some of them are stated by both female and male interviewees. One of them, for example, is the ability of "identifying your needs and deficiencies" as a learner. Both female and male interviewees define it as an important ability because identifying needs and deficiencies make learners aware of the learning process. Both genders also state that "having curiosity and interest in learning" as an ability in language learning is useful because it helps learners to develop their language. One of the most uttered ability by both genders is the ability of "knowing yourself' in language learning. They define knowing yourself as an important ability in language learning because knowing yourself may mean knowing your learning styles, your desires, your needs, that is, everything related to you as a learner. A female interviewee explains this ability with knowing or being aware of what she has learned before. Additionally, both female and male interviewees state that "knowing weaknesses and strengths of yourself" makes you realize what you need most; and therefore, you can organize your learning according to your strengths and weaknesses in language learning. For both female and male interviewees, "having a strong memory" should be one of the fundamental abilities of learners, since they need to memorize many words and rules of the target language. They also add that learners should have the ability to "make choices" in the learning process. Making choices is an important ability in language learning because learners need to make choices, for example in activities, materials etc. in order to be autonomous learners. Besides this, both female and male interviewees clarify that "being social" is a beneficial ability that learners should have in language learning because language, itself, can be regarded as a product of social interaction. 


\subsection{Gender and Turkish ELT Students' Perceptions Related to Activities on Learner Autonomy}

Figure 3.6. shows the relationship between the perceptions of learners related to activities and gender.

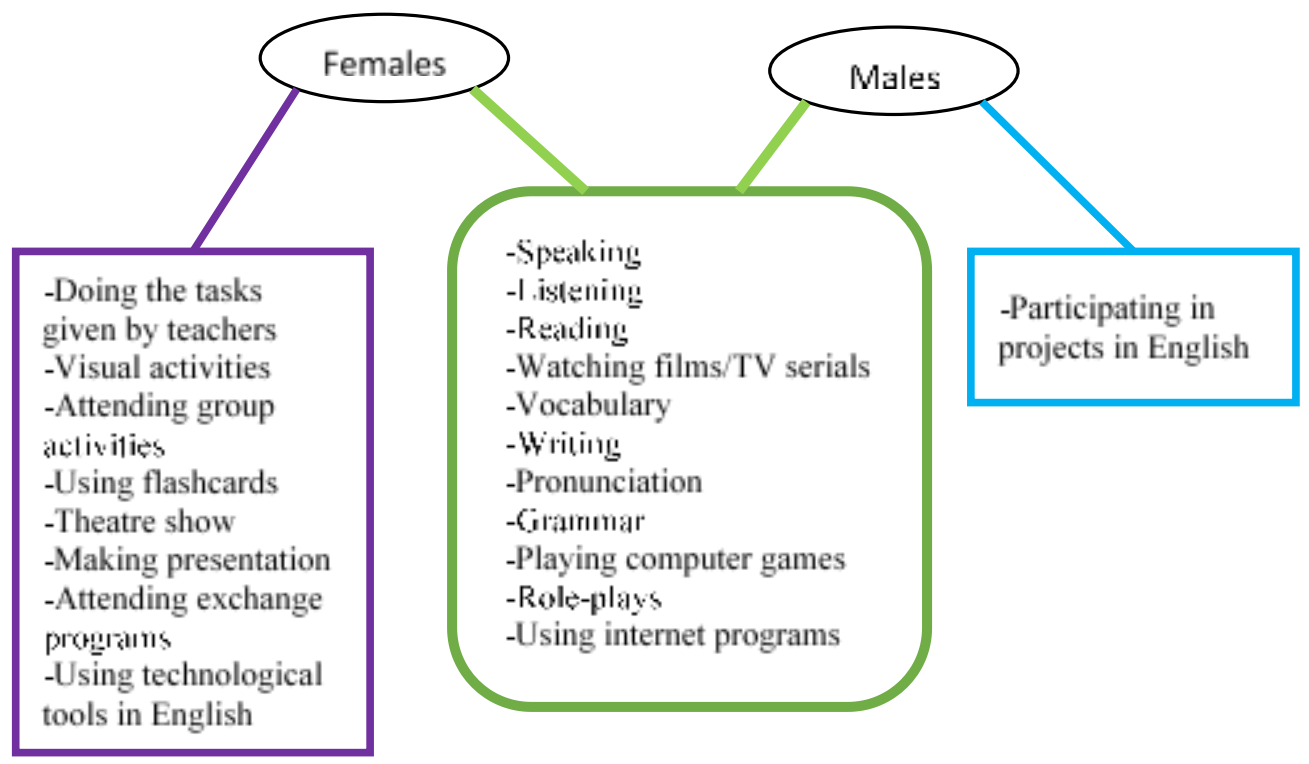

Figure 6. The relationship between the perceptions of learners related to activities and gender

When we look through the interview data, we see that both female and male interviewees report the similar activities in language learning. They state that learning can be achieved through communicating with others;

therefore, "speaking and listening activities" are highly emphasized. It is also stated that doing activities on the other language skills such as reading and writing as well as vocabulary can be beneficial for increasing the knowledge in the target language.

As mentioned earlier, perceptions of Turkish ELT students is in the direction of choosing enjoyable activities, specifically "watching films and TV series" regardless of the genders of the interviewees. In other words, both female and male interviewees state that they watch films, TV series, cartoons, etc. to learn new things, new words, in the target language. Besides, a number of interviewees agree that a language is a tool for communication and learners should know how to pronounce the words correctly. They state that they care about having a target like speaking, thus they do pronunciation activities to be able to speak with English accent. In addition, both female and male interviewees state that "playing computer games" can be useful for learners because one can learn new vocabulary through playing computer games with great fun. Furthermore, both female and male interviewees state that "role play activities" can be used to create an authentic atmosphere for learners to use the language. Additionally, the influence of technology on education is increasing with the developments in educational technologies. It is therefore natural to see many applications to be used in language learning for learners. Not surprisingly, both female and male learners approve that they "use online sources" to enlarge their knowledge in the target language.

\subsection{Autonomy Definitions}

One of the important findings in the interview data is the participants' learner autonomy definitions. The interview findings reveal that the definition of learner autonomy cannot be narrowed down with a few expressions. In other words, the definition of learner autonomy should include all the things that affect the learning process. The interviewees define learner autonomy as:

- Being aware of your duties, responsibilities and implementing them

- Knowing your strengths and weaknesses

- Being responsible for your learning process

- Participating the learning processes 
- Being aware of your progress

- Being ready for acquiring the knowledge

- Being curious about learning

- To be able to organize your own learning process

- To be able to reach the expected goals in learning

- To be able to control your own learning process

- Being involved in decision-making processes

- Being in the center of learning

- Being aware of what to do

As understood from the definitions of interviewees, learner autonomy can be discussed in many aspects. In general, learner autonomy definitions can be organized as follows: (1) learners' active involvement to the learning process, (2) self-realization of learners, and (3) being responsible for organizing/controlling learning process. Learners' active involvement means being active and responsible for their own learning. To do this, learners should be actively involved in the tasks and do the activities to increase their knowledge in the target language. On the other hand, self-realization of yourself can be explained with learners' being aware of their conditions. Lastly, being responsible for organizing/ controlling can be explained by sharing responsibility with teachers in decision-making processes.

\section{Discussion}

\subsection{The Relationship between the Year of Study and Learner Autonomy}

In the current study, out of 20 interviewees, 12 state that both learners and teachers should share the responsibilities, although 6 interviewees argue that learners should have more responsibilities than the teachers have, and only 2 interviewees accept that teachers should be more responsible in language learning. In Ylldırım's study (2005) majority of the learners believe that learners should be responsible as well as teachers. In other words, it can be understood that learners are aware of how important taking active roles are and they agree that teachers' support in language learning is indispensable. In addition, in Cotteral's study (1999), 76 percent of the participants state that learners should be given responsibilities in order to find opportunities to experience the language. In this regard, Tanyeli and Kuter (2013) say that learners' taking responsibilities for their own learning is beneficial, and teachers should help learners take responsibilities for their own learning. In order to develop the perceptions of learners related to responsibilities in language learning, it can be said that the relationship between teachers and learners must be strengthened because learners cannot be autonomous without the support of their teachers (Arshiyan \& Pishkar, 2015).

However, constructing learners' willingness to take responsibilities is not easy. In other words, learners need to gain experience in taking responsibilities for their learning. In Okumuş Ceylan's study (2015), which focuses on strategy training on learner autonomy and achievements of learners in language learning, learners accept that they should be responsible for their learning, but, they see their teachers as authority figures because of their experience in language learning, and they perceive that teachers are experts on how to teach/learn a language. In addition, Chan, Spratt, and Humphreys (2002) state that learners believe that teachers should be responsible for a number of issues such as selecting the materials in language learning. This is because learners believe that they do not have experience in such issues, but teachers have, and therefore, teachers can reach the right decision in selecting the materials or deciding on the activities in language learning.

The interviewees also state that learners should have the ability to know themselves in language learning. It can be deduced that knowing yourself can be achieved through identifying how much you are aware of yourself, therefore evaluating your learning is also an important ability to know your development in language learning. At this point, Arshiyan and Pishkar (2015) reveal that nearly 80 percent of teachers believe that learners should be able to evaluate themselves to increase their knowledge in the target language. They also state that learners should be competent in monitoring their learning, as it is crucial to define how close you are to your goals in language learning. In other words, learners' ability to monitor themselves and self-assessment are the key elements in language learning and promoting learner autonomy, as well.

The interview data has revealed that learners apply a wide range of activities in language learning such as reading books, newspapers, watching TV and movies, practicing English with their friends, etc. On the other hand, participants' perceptions related to activity choices indicate that they are generally in favor of activities which focus 
on developing the communicative aspect of language such as speaking with natives, or activities for developing listening and speaking skills such as watching English movies. This shows the learners' tendency towards using/learning a language for communicative purposes. Therefore, teachers should give learners opportunities to reinforce experience (Ahmadzadeh \& Zabardast, 2014) in using the target language.

\subsection{The Relationship between Gender and Learner Autonomy}

Interview data reveal that evaluating the course is an important responsibility for both genders in language learning. In other words, it can be concluded that evaluating the course is an important responsibility to be acquired in language learning. This result is also supported by the study of Spratt, Humphreys, and Chan (2002), in which "evaluating the course" is found significantly an important responsibility for the learners.

The interview data analysis also indicates that both female and male participants want to take active roles in language learning. An interviewee (female) states that being autonomous for learners is so important because teachers can only be helpful to the learners in the classroom. The role of the learner is to be responsible for his/her learning as much as possible. In this regard, Sakai, Takagi, and Chu (2010) find that more than 35 percent of the learners expect to take part in deciding the goal of the study, deciding the materials and textbooks, and checking their progress.

Being autonomous or promoting autonomy can be achieved through reducing dependency to teachers. Leathwood (2006) argues that learners expect to be more independent especially in universities. However, according to Leathwood, the problem with independence is not taking responsibilities, but not to be supported by teachers. Therefore, learners should be active and responsible for their learning process because being responsible is essential in learning a language (Tanyeli \& Kuter, 2013) and learners need to gain their independence and work in cooperation with others.

It can be said that learners want to take responsibilities for their own learning because they think they are component in taking active roles in language learning. However, Üstünoğlu (2009) finds that teachers do not want to give responsibilities to the learners because of fear of losing their power and control over the classroom. Dependence to teachers hinders the promotion of learner autonomy, therefore both female and male learners should be taught to be aware of their responsibilities in language learning because unawareness of learners increases the dependency to the teachers (Chan, Spratt, \& Humphreys, 2002).

Interestingly, Üstünoğlu (2009) reports that although learners regard themselves able to evaluate, choose, and decide on the materials and activities to be used in classes, they prefer to give the responsibility to the teachers. One of the reasons for this is that teachers have more experience in language learning than the students. In addition, although they are aware of how important learner autonomy is, they accept the teachers as authority figures. In this regard, teachers should support their students to gain control over learning because learner autonomy can be defined as a situation where learners act independently and define their needs and make their own choices (Tanyeli \& Kuter, 2013).

Additionally, interview data analysis approves that female students consider a great variety of activities when compared to male students although they share certain basic language learning activities such as listening to songs, browsing the internet in English. In the study of Chan, Spratt, and Humphreys (2002), they realize that there is no difference between the students whose major is English and the other student in the engagement of the language learning activities. Therefore, motivation level of learners has a strong influence on the learner participation to the activities.

\subsection{Autonomy Definitions}

Definitions of terms and concepts are generally made by the researchers or the scholars who have deeper knowledge in a specific area. Sometimes the definitions of these terms may not be understood clearly by the learners of these terms because of several reasons such as the complexity of the term or being too abstract to be understood. When the definitions of such concepts are made by the learners of these concepts, it can be understood how much learners grasp the meaning of the concept, especially if the concept is multifaceted such as learner autonomy (Atkinson, 1999). Besides, definitions of terms and concepts make explicit the implicit meaning and this explicit meaning can be analyzed by the learners (Kikas, 1998). The rigid definitions of terms made by scholars may also limit understanding and create barriers for learners; therefore, the students' definitions on a concept may be quite valuable. In this regard, the present research reveals how a group of Turkish ELT students define learner autonomy. 


\section{References}

Ahmadzadeh, R. \& Zabardast, S. (2014). Learner Autonomy in Practice. International Journal on New Trends in Education \& Their Implications, 5(4), 49- 57.

Arshiyan, P. \& Pishkar, K. (2015). A survey of the lecturers' perception about EFL Azad University students' autonomy versus actual level of autonomy. Theory and Practice in Language Studies, 5(11), 2277-2286. https://doi.org/10.17507/tpls.0511.11

Atkinson, D. (1999). TESOL and culture. TESOL Quarterly, 33(4), 625- 654. https://doi.org/10.2307/3587880

Brown, H. D. (2007). Principles of Language Learning and Teaching. New York: Pearson Education Inc.

Chan, V. (2001). Readiness for Learner Autonomy: What do our learners tell us? Teaching in Higher Education, 6(4), 504- 518. https://doi.org/10.1080/13562510120078045

Chan, V., Spratt, M., \& Humphreys, G. (2002). Autonomous language learning: Hong Kong tertiary students' attitudes and behaviours. Evaluation \& Research in Education, 16(1), 1- 18. https://doi.org/10.1080/09500790208667003

Cotteral, S. (1999). Key variables in language learning: what do learners believe about them? System, 27, 493- 513. https://doi.org/10.1016/S0346-251X(99)00047-0

Cresswell, J. W. (2013). Research design: Qualitative, quantitative, and mixed methods approaches (4th Ed). London: SAGE Publications.

Holec, H. (1981). Autonomy and Foreign Language Learning. Oxford: Pergamon.

Holliday, A. (2003). Social autonomy: Addressing the dangers of culturalism in Tesol. In D. Palfreyman, Learner Autonomy across Cultures (pp. 110- 128). New York: Palgrave Macmillan. https://doi.org/10.1057/9780230504684_7

Kikas, E. (1998). The impact of teaching on students' definitions and explanations of astronomical phenomena. Learning and Instruction, 8(5), 439- 454. https://doi.org/10.1016/S0959-4752(98)00004-8

Kristmanson, P., Lafargue, C., \& Culligan, K. (2013). Experiences with autonomy: Learners' voices on language learning. Canadian Modern Language Review, 69(4), 462-486. https://doi.org/10.3138/cmlr.1723.462

Leathwood. (2006). Gender, equity and the discourse of the independent learner in higher education. Higher Education, 52, 611- 633. https://doi.org/10.1007/s10734-005-2414-3

Little, D. (1991). Learner Autonomy 1: Definitions, Issues, and Problems. Dublin: Authentik.

Little, D. (1995). Learning as dialogue: The dependence of learner autonomy on teacher autonomy. System, 23(2), 175-181. https://doi.org/10.1016/0346-251X(95)00006-6

Liu, N. F. \& Littlewood, W. (1997). Why do many students appear reluctant to participate in classroom learning discourse? System, 25(3), 371-384. https://doi.org/10.1016/S0346-251X(97)00029-8

Miles, M. B., Huberman, A. M. \& Saldana, J. (2014). Qualitative data analysis: A sourcebook. New York: Sage.

Okumuş Ceylan, N. (2015). Fostering learner autonomy. Procedia - Social and Behavioral Sciences, 199, 85- 93. https://doi.org/10.1016/j.sbspro.2015.07.491

Onwuegbuzie, A. J. \& Collins, K. M. (2007). A typology of mixed methods sampling designs in social science research. The Qualitative Report, 12(2), 281- 316.

Palfreyman, D. (2003). Introduction: Culture and Learner Autonomy. In D. Palfreyman, Learner Autonomy across Cultures (pp. 1- 22). New York: Palgrave Macmillan. https://doi.org/10.1057/9780230504684_1

Reinders, H. (2010). Towards a classroom pedagogy for learner autonomy: A framework of independent language learning skills. The Australian Journal of Teacher Education, 35(5), 1-17. https://doi.org/10.14221/ajte.2010v35n5.4

Richards, J. C. \& Rodgers, T. S. (2001). Approaches and Methods in Language Teaching. Cambridge: Cambridge University Press. https://doi.org/10.1017/CBO9780511667305

Richards, J. C. \& Schmidt, R. (2010). Longman Dictionary of Language Teaching and Applied Linguistics. Pearson Education Limited.

Sakai, S., Takagi, A. \& Chu, M. P. (2010). Promoting learner autonomy: Student perceptions of responsibilities in a 
language classroom in East Asia. Educational Perspectives, 43, 12-27.

Saldaña, J. (2009). The coding manual for qualitative researchers. London: Sage.

Spratt, M., Humphreys, G. \& Chan, V. (2002). Autonomy and motivation: which comes first? Language teaching research, 6(3), 245- 266. https://doi.org/10.1191/13621688021r106oa

Tanyeli, N. \& Kuter, S. (2013). Examining Learner Autonomy in Foreign Language Learning and Instruction. Eurasian Journal of Educational Research, 53, 19- 36.

Üstünoğlu, E. (2009). Autonomy in language learning: Do student take responsibility for their learning. Journal of Theory and Practice in Education, 5(2), 148- 169.

Yıldırım, Ö. (2005). ELT Students' Perceptions and Behavior Related to Learner Autonomy as Learners and Future Teachers. Unpublished MA Thesis, Eskişehir: Anadolu University. 